\title{
ON THE DISTRIBUTION OF THE GROUP TAX BASES ACROSS THE EU: THE STUDY FOR THE CZECH REPUBLIC
}

\section{Danuše Nerudová, Veronika Solilová*}

\begin{abstract}
:
The introduction of the CCCTB system in the European Union will have the impact on the redistribution of the group tax bases between the Member States and therefore also on the national budgets. The aim of the paper is to quantify the differences in the division of the MNEs group tax bases between the individual Member States in current situation - i.e. when applying separate entity approach and situation when CССTB will be introduced - i.e. applying the allocation formula for sharing the tax base. The results show that the Czech Republic could gain in situation when CCCTB would be introduced in all EU Members States - the share in the group tax base would increase by $1.22 \%$. A very slight increase was also indicated in the case of the Slovak Republic, Slovenia and Spain. On the contrary, the share in the group tax base was decreased in the case of Germany (by 1.36\%), Estonia, Hungary and Poland. The results also indicate that there might be connection between the size of the country and the impact on the share of the tax base.
\end{abstract}

Keywords: CCCTB, group, tax base, sharing mechanism, Czech Republic JEL Classification: $\mathrm{H} 25, \mathrm{~K} 22$

\section{Introduction}

Common Consolidated Corporate Tax Base represents one of the most ambitious projects in the history of the harmonization efforts within the European Union. The efforts in the area of direct taxation have never gone so far. The European Commission proposed the system allowing for "one-stop-shop" for filling the tax return and consolidating profits and losses within the EU while retaining the right of EU Member States to set their own corporate tax rate. That design which brings the directive proposal from $16^{\text {th }}$ March, 2011, is resulting into the reduction of compliance costs of taxation, elimination of internal transfer pricing and to establishment of the possibility of internal cross-border off-setting of losses and profits. The European Commission also believes, that implementation of CCCTB system should lead to the fair tax competition, because the harmonization of the rules for tax base construction means that the nominal tax rates will fully reflect the real tax burden falling on the companies - i.e. will be equal to the effective tax 
rate. The implementation of the CCCTB system can also increase the competitiveness of the EU companies on the global market and as mentions Szarowska (2010) it can have an impact on the EU economy growth.

The introduction of CCCTB system will contribute to the elimination of the obstacles for the international mergers and acquisitions, resulting from the lack of coordination of capital profit taxation. On the other hand, the system will also be connected with some disadvantages. The existence of two systems (CCCTB and national system) leaves the space for speculations, tax arbitrations, tax evasion and fraud. In order to limit the possibility of speculations and tax arbitrations, the proposal of CCCTB system covers strict rules for getting in and getting out of the system.

Cross-border consolidation is connected with the problem of tax sharing mechanism. The directive proposal suggests the allocation formula. Its impact on EU Member States budgets is the subject of great discussion. The reason is the fact that at present, enterprises belonging to the MNEs groups are mostly taxed as separate entities in the state of their residence without the possibility of the consolidation for tax purposes. However, under CCCTB system MNEs group will be able to create one group for taxation purposes and to consolidate its profits and losses. The consolidated tax base of the MNEs group will be shared among the Member States according the allocation formula, taking into account the location of assets, labour force and sales of the enterprise. Even though the Member States will have a right to set the corporate income tax rate, they are going to impose the tax rate on the tax bases, which will be different from the current situation when separate entity (hereinafter as SA) is applied. Based on that, the Member States will also raise different tax revenues.

The aim of the paper is to quantify the differences in the division of the MNEs group tax bases between the individual Member States in current situation - i.e. when applying separate entity approach and situation when CCCTB will be introduced - i.e. applying the allocation formula for sharing the tax base. The empirical analysis is based on the data available from the Amadeus database. The paper presents the results of the research within the Project GA CR No. 13-21683S “The Quantification of the Impact of the Introduction of Common Consolidated Corporate Tax Base on the Budget Revenues in the Czech Republic”.

\section{Theoretical Background}

At present, there can be identified two approaches in treatment of MNEs tax bases separate accounting approach (hereinafter as SA) and unitary approach (hereinafter as UA). Many countries are using separate accounting for dividing the total tax base of an MNE among the jurisdictions. As mentions Oestreicher (2000) SA method splits an MNE into hypothetically unrelated enterprises, expected to bargain with each other like independents. And Kumpf (1976) adds that those enterprises are expected to bargain with each other like independents. Oestreicher (2000) further specifies that each subsidiary or branch of MNE is treated as separate entity that deals at arm's length with its parent and other associated entities. Those entities are completing financial accounts and exterminating the profit according the rules comprised in the taxation systems in each location. The parent company has to calculate its financial account as each of its enterprise would be independent entity - i.e. all the transactions between the members of the group have to be at arm's length. As mentions Bakker (2009) under arm's length principle, affiliated 
businesses should set transfer prices at levels that would have prevailed that the transaction occurred between unrelated parties. Solilová and Nerudová (2013) add that arms' length principle was established to protect the manipulation of transfer price. As mentions OECD (2001), the arm's length principle eliminates tax consequences that could arise solely from the organizational form of the enterprise. However, as mentions Picciotto (1992) financial records of the enterprises can be adjusted by local tax authorities to reflect profit or loss which would have been reached in situation when all internal transfers would be realized under open-market conditions. And as mentions Vann (1991) even though the MNEs may take advantage arising from the tax differentials, they are most frequently accused by fiscal administrators of manipulating their transfer prices. Solilová and Nerudová (2012) add that nowadays changes in economic environment have forced governments and MNEs to focus on the more accurate arm's length transfer prices and more successful business model.

SA approach is based on two principles - the concept of separate entity theory and arm's length principle. As mentions Jacobs (2002) while the separate personality of fullfledged subsidiary is logically stemming from the incorporation in respective country, the attribution of the taxable income to a branch segregated from the entity to which it legally belongs is more complicated. In order to achieve the above mentioned, functional and factual analysis has to be performed. As mention Djanani and Brahler (2006), second principle - arm's length principle - is currently the international standard of taxing MNEs. Under that principle, tax authority considers inter-company transaction as appropriate if the conditions of the contract are comparable with the conditions which would be concluded between two independent entities.

On the contrary, unitary approach is based on three principles - unitary entity theory, worldwide reporting and formulary apportionment. As mentions Weiner (1999), the unitary approach looks on the economic substance of the entity and tries to integrate multi-entity operation into single unit for income tax purposes. Weiner and Mintz (2002) further add that formulary apportionment (in the frame of unitary approach) represents a technique under which the cross-country consolidated tax base of MNEs is split across jurisdictions according to the defined formula comprising factors reflecting the way the companies generate profit. Formulary apportionment is at present applied for example in the USA or Canada. On the contrary to the SA approach apportionment the tax base is shared according to the allocation formula, taking into account the different factors as for example assets, labour force or sales of the enterprise. As McDaniel (1994) mentions that contrary to the SA approach, formulary apportionment is based on different premises, it has different economic effects and presents different technical issues, although the problems arm's length method are not among them. Under unitary apportionment substance-over-form principle is applied. The European Commission in the frame of CCCTB system decided for formulary apportionment, which is used with slight differences in the factors of the formula applied for example in the USA or Canada.

Under formulary apportionment within the CCCTB rules, the member of the group can calculate its share on the profit based on the activities, which are conducted in its location. When applying the formula, there is no need for MNE to calculate the profit earned by each member of the group. As mentions Sorensen (2004) and Devereux (2004) formulary apportionment can be regarded as a system of source taxation. 
Allocation formulas can be divided according the factors which are used for allocation on macro-based formula and micro-based formula. While applying micro-based formula, two approaches can be used - value added approach and formulary apportionment approach. Selected formula can influence the portion on the tax base in dependence on the factors which are used. The basic criteria which should be met by the method of apportionment are fairness, enforceability, simplicity and cost-efficiency. All these possible tools for tax sharing mechanisms were discussed in details by (Nerudová, 2011). In that connection also Devereux and Loretz (2008) conclude that introduction of the formulary apportionment system would have some desirable efficiency effects.

The first scientific work, which has been focused on sharing mechanism, concretely on formulary apportionment, was done by Musgrave (1972), who pointed out that formulary apportionment could eliminate the problem with transfer pricing within multinational corporations. Miller (1984) mentions that the formula should reflect the elements measuring the processes involved in the earning of net income and that formula should be easy to administer. Later Gordon and Wilson (1986) examined how corporate taxation of multinational firms using formula apportionment affects the incentives faced by individual firms and individual states. Musgrave (1984) defined two basic views on the formula (with respect to the fact where the profit originates) - supply-based and supply-demand based view. McLure (1980) has proved that when a formula consists of the factors as property of the company, payroll and sales, corporate income tax transforms into a tax on property, payroll and sales. This has also been proved by Goolsbee, and Maydew (2000). Also Wellish (2000) shows, that when a labour is used as the factor, then the costs of labour are exceeding the local wage rate, which reduces the demand for labour in each state.

The possible methods of sharing the tax base, mainly the formulary apportionment in the conditions of the EU has been discussed by Hellerstein and McLure (2004), who emphasize that the EU should learn from the US and Canadian experience with formulary apportionment. Also Weiner (2005) and Mintz (2004) stipulate several problems of US and Canadian experience that could be useful for EU corporate taxation. The problem of the sharing mechanism within the EU and possible proposals has been discussed by Sorensen (2004), Devereux (2004) or Agúndez-García (2006). Another authors as Lodin and Gammie (2001) were focusing on value added based apportionment. Also Hellerstein and McLure (2004) were analysing value added approach in their study.

The impacts of СССТВ introduction in the EU15 have been researched by Fuest, Hemmelgarn, Ramb (2006), who concluded that Ireland, Belgium and the Netherlands will lose a significant part of their tax base, while larger countries will lose less tax base. Devereux and Loretz (2007) in their static model deduce that overall EU tax revenues would decline by $1 \%$ and that the new EU countries as the Slovak Republic, Hungary and to a lesser extent also the Czech Republic would gain increased tax revenue. Bettendorf, van der Horst, de Mooij and Vrijburg (2010) arrived to a similar conclusion that under formulary apportionment with three equally weighted factors as employment, assets and output will benefit countries in Central and Eastern Europe at the expense of a number of capital-intensive countries in Western Europe. 


\section{Data and Methodology}

The empirical analysis is based on the company-level data from the Amadeus database which is provided by Bureau van Dijk. These data were taken from update 227 (August 2013) of the database including standardized financial information of more than 18 million public and private companies in 43 European countries.

In the paper the authors use the similar assumption as Devereux and Loretz (2007) that corporations do not change their behaviour in response to the tax reform, which provides a useful benchmark for the analysis. Further, the paper follows the approach of Devereux and Loretz (2007), Fuest, Hemmelgarn and Ramb (2006) or Clien, Neubig, Phillips, Sanger and Walsh (2010) which is based on the data from the Amadeus database due to the fact that it contains data on more than 18 million companies.

With respect to the fact that the paper presents the results of the first stage of the research which aims at the research of the budgetary impacts of the CСCTB introduction for the Czech Republic, it was needed to gain the group of EU companies, which would under CCCTB system qualify for consolidation regime and group treatment. Therefore only European companies (EU28) fulfilling the two-tier test confirming the eligibility for consolidation (group membership) were further analysed. This test consists of two layers control, which is assumed if the controlling company holds at least $50.01 \%$ in the controlled company and ownership, which is assumed if the ownership rights amount to more than $75 \%$ of the company's capital.

In the next step the gained sample of companies was researched in order to identified parent company and its subsidiaries in the EU Member States. Based on that analysis we gained the distribution of the subsidiaries among the EU Member States.

Secondly, the detailed analysis of the situation in the Czech Republic was done. The financial statements of the parents situated in the Czech Republic as well as subsidiaries situated in the EU Member States were researched in order to gain their profit or loss before taxation.

In order to identify the shares of individual EU Member States in group tax bases, the detail comparative analysis of group taxation schemes and consolidation regimes was done. Based on that the EU Member States were categorized in to the four groups according the rules they are applying. Those rules were then used to calculate the total tax base of subsidiaries of the Czech parent companies in respective EU Member States.

In the next step, the sharing of the group tax base according to the allocation formula in individual EU Member States was researched. The proposed formulary apportionment under CCCTB comprises three factor formula equally weighted according the factors of sales, labour and assets:

$$
\text { Share } A=\left(\frac{1}{3} \frac{S^{A}}{S^{\text {group }}}+\frac{1}{3}\left(\frac{1}{2} \frac{P^{A}}{P^{\text {Group }}}+\frac{1}{2} \frac{E^{A}}{E^{\text {Group }}}\right)+\frac{1}{3} \frac{A^{A}}{A^{\text {Group }}}\right) * \text { CССТB }
$$

where S represents sales, which are based on the sales of goods and services. P represents payroll, which includes the costs of salaries, wages, bonuses and all other employee compensation, including related pension and social security costs borne by the employer. E represents the number of employees, which are considered part of the group that pays the remuneration, unless they are under the control of a different group member, in which case they are considered part of that group. Employees are included if they are employed 
for at least three uninterrupted months. And finally, A represents assets, which include all fixed tangible assets, including buildings, airplanes and machinery, owned, rented, or leased by a group member.

The data were gained from the accounting reports of the companies from the Amadeus database. However, the required information (operating revenue, number of employees, cost of employees, tangible fixed assets) from accounting reports of individual companies was often missing in Amadeus database. In order to allow more companies to be covered into the analysis, two methods, namely the method of imputation and regression, were applied. The decision, which method is more suitable for supplementing the data and consequently used for the determination of tax base, was based on the comparison of their average deviations from real data.

Firstly, both of methods were applied on the data that includes companies from the ten largest NACE $^{1}$ codes of the group that presents the parent companies situated in the Czech Republic and their subsidiaries in the EU (hereinafter Group 1). The results are presented in the first line of the following table.

Then both of methods were again applied, however, on the data that includes companies from the largest section of NACE of the group that presents the parent companies situated in the EU and their subsidiaries in the EU (hereinafter Group 2). After that, the coefficients from the received regression of the Group 2 were applied on the same section of NACE of the Group 1. The results are presented in the second line of the Table 1 below.

As can be seen, the method of imputation presents better results of average deviations in both cases. Therefore, the method of imputation was used for supplementing the data and consequently for determination of the tax base.

Table 1 | Comparative Analysis of the Different Methodology Applied on Missing Data

\begin{tabular}{|c|c|c|c|c|}
\hline Data & Type of method & $\begin{array}{c}\text { Operating } \\
\text { Revenue } \\
\text { in the EUR }\end{array}$ & $\begin{array}{l}\text { No. } \\
\text { Employees } \\
\text { in the EUR }\end{array}$ & $\begin{array}{l}\text { Cost of } \\
\text { Employees } \\
\text { in the EUR }\end{array}$ \\
\hline \multirow{4}{*}{$\begin{array}{l}\text { Parent } \\
\text { company } \\
\text { in CZ and } \\
\text { subsidiaries } \\
\text { in EU - Group } 1\end{array}$} & Imputations & & & \\
\hline & Average deviation from reality & -11.61 & -8.08 & -267.45 \\
\hline & Regression & & & \\
\hline & Average deviation from reality & -17.04 & -14.45 & -415.27 \\
\hline \multirow{4}{*}{$\begin{array}{l}\text { Parent } \\
\text { company } \\
\text { in EU and } \\
\text { subsidiaries } \\
\text { in EU - Group } 2\end{array}$} & Imputations & & & \\
\hline & Average deviation from reality & -42.71 & -23.38 & $-1,007.73$ \\
\hline & Regression & & & \\
\hline & Average deviation from reality & -94.43 & -40.56 & $-1,246.92$ \\
\hline
\end{tabular}

Source: Own research, Amadeus database.

1 NACE - European industrial activity classification. Namely, NACE Codes 1, 25, 35, 41, 43, 46, 47, 68, 70 and 71. 
The method of imputation is based on the observed data for companies in the same industry for Eastern and Western Europe (i.e. the EU-13 and EU-15). Furthermore, as already applied by Cline et al. (2010), missing operating revenue, number of employees, and costs of employees were imputed using ratios of the factor to assets for companies in which both variables are observed. Companies reporting fixed assets as not available were excluded from the imputation. Similarly, missing operating revenue amounts were imputed using reported tangible fixed asset data and the ratio of observed operating revenue to the tangible fixed assets for other companies. Missing employee data were imputed based on the reported tangible fixed assets of the company and the ratio of reported employees to tangible fixed assets. And finally, as already applied by Cline et al. (2010), missing cost of employment data were imputed based on the reported or imputed employee headcount and the ratio of cost of employees and employee headcount for companies reporting both items.

There are used standard scientific research methods in the paper. The paper is divided into theoretical and empirical part. In the first theoretical part the method of description and analysis was applied in order to research the current state of research with respect to the methods of group tax base apportioning among the relevant jurisdiction. The empirical part of the paper presents the empirical analysis of the EU companies comprised in Amadeus database, where the method of analysis and synthesis was applied. And further, in order to categorize EU Member States according to the applied group taxation and consolidation rules, the method of comparative analysis was applied. Finally in calculation of the shares of the tax base of individual member states as well as in the conclusions the method of induction, deduction and synthesis was applied.

\section{Results}

As was already said above, at present, enterprises belonging to the MNEs group are in most cases (except for those, who are tax residents in the Netherlands) taxed as separate entities in the state of their residence without the possibility of the consolidation for tax purposes - i.e. separate entity approach is applied. Due to this fact the introduction of CCCTB system will change the shares of EU Member States in group tax bases especially in countries not allowing the consolidation or group taxation schemes.

In order to fulfill the aim of the research - to draw the map of the division of the MNEs group taxes base between the individual Member States in current situation (with special focus on the Czech Republic) - there were selected companies from Amadeus database, which are resident in one of the EU Member States. After that selection we received the sample of more than 15,000,000 companies. These companies were tested by the two-part test, firstly, if they fulfill the control part (here we gained the sample of 182,636 companies) and then the ownership part of the test (here we gained the sample of 163,401 companies). As revealed detailed analysis, these companies have 377,781 subsidiaries within the EU-28. Secondly, based on the BvD ID number (identification number of the company in the Amadeus database which is based on national identification number) of the subsidiaries. These ID numbers were than imported back into Amadeus database. The reload of these ID numbers identified approximately $10 \%$ of subsidiaries which are not available on Amadeus; their ID number is recorded only by their mother companies. Following Table 2 presents the residency of parent companies and subsidiaries which met the criteria of two-tier test in individual Member States. 
Table 2 | Parent and Subsidiaries Fulfilling Two-Tier Test

\begin{tabular}{|c|c|c|c|c|}
\hline \multirow{3}{*}{$\begin{array}{l}\text { Country } \\
\text { ISO code }\end{array}$} & \multicolumn{4}{|c|}{ Two-tier test fulfillment } \\
\hline & \multicolumn{2}{|c|}{ Parents EU } & \multicolumn{2}{|c|}{ Subsidiaries EU } \\
\hline & Absolutely & Relatively & Absolutely & Relatively \\
\hline AT & 2,293 & $1.4 \%$ & 5,113 & $1.4 \%$ \\
\hline BE & 2,213 & $1.4 \%$ & 6,069 & $1.6 \%$ \\
\hline BG & 2,252 & $1.4 \%$ & 0 & $0.0 \%$ \\
\hline CY & 863 & $0.5 \%$ & 1,982 & $0.5 \%$ \\
\hline CZ & 2,764 & $1.7 \%$ & $6,210 *$ & $1.6 \%$ \\
\hline DE & 18,885 & $11.6 \%$ & 48,726 & $12.9 \%$ \\
\hline DK & 13,687 & $8.4 \%$ & 20,372 & $5.4 \%$ \\
\hline EE & 1,929 & $1.2 \%$ & 3,259 & $0.9 \%$ \\
\hline ES & 7,436 & $4.6 \%$ & 19,978 & $5.3 \%$ \\
\hline FI & 1,452 & $0.9 \%$ & 4,047 & $1.1 \%$ \\
\hline FR & 12,883 & $7.9 \%$ & 35,932 & $9.5 \%$ \\
\hline GB & 62,954 & $38.5 \%$ & 147,965 & $39.2 \%$ \\
\hline GR & 496 & $0.3 \%$ & 1,512 & $0.4 \%$ \\
\hline HR & 34 & $0.0 \%$ & 0 & $0.0 \%$ \\
\hline HU & 38 & $0.0 \%$ & 848 & $0.2 \%$ \\
\hline IE & 3,814 & $2.3 \%$ & 7,438 & $2.0 \%$ \\
\hline IT & 15,518 & $9.5 \%$ & 29,509 & $7.8 \%$ \\
\hline LT & 157 & $0.1 \%$ & 742 & $0.2 \%$ \\
\hline LU & 682 & $0.4 \%$ & 2,019 & $0.5 \%$ \\
\hline LV & 135 & $0.1 \%$ & 543 & $0.1 \%$ \\
\hline MT & 58 & $0.0 \%$ & 241 & $0.1 \%$ \\
\hline NL & 4,609 & $2.8 \%$ & 14,139 & $3.7 \%$ \\
\hline PL & 2,447 & $1.5 \%$ & 7,975 & $2.1 \%$ \\
\hline PT & 1,656 & $1.0 \%$ & 3,805 & $1.0 \%$ \\
\hline RO & 1,084 & $0.7 \%$ & 0 & $0.0 \%$ \\
\hline SE & 2,237 & $1.4 \%$ & 7,979 & $2.1 \%$ \\
\hline SI & 186 & $0.1 \%$ & 579 & $0.2 \%$ \\
\hline SK & 156 & $0.1 \%$ & 799 & $0.2 \%$ \\
\hline n.a. & 483 & $0.3 \%$ & 0 & $0 \%$ \\
\hline TOTAL & 163,401 & $100.0 \%$ & 377,781 & $100.0 \%$ \\
\hline
\end{tabular}

Note: n.a. - location of the company is not available in Amadeus database

*the number covers all subsidiaries in the Czech Republic fulfilling the two-tier test.

Source: Own research from Amadeus database 
Further, the attention was focused on the situation in the Czech Republic. As can be seen from the previous Table 1, there were identified 2,764 parent companies fulfilling the two-tire test in the Czech Republic. From 6,210 subsidiaries resident in the Czech Republic (fulfilling the two-tire test) there were selected only subsidiaries, which are owned by the parent company, residing in the Czech Republic. After that selection, there were identified 4,558 subsidiaries of the Czech parent companies residing in the EU-28. The subsidiaries were imported back to Amadeus database for the assignation to the parent company and 3,970 EU subsidiaries were available, assignable to 2,488 CZ companies. In order to calculate the share of the Member State in the group tax base, the filter of availability of the information on profit or loss before taxation was applied. After that we have received the sample of 2,440 subsidiaries of the Czech parent companies providing the information about their profit or loss before taxation. The result is shown in following Table 3.

Table 3 | The Residency of the Subsidiaries of the Czech Parent Companies in Individual EU Member States

\begin{tabular}{|l|c|c|}
\hline \multicolumn{3}{|c|}{$\begin{array}{c}\text { Subsidiaries of Czech Parents with } \\
\text { the information about P/L before taxation }\end{array}$} \\
\hline AT & 0 & $0.0 \%$ \\
\hline BE & 0 & $0.0 \%$ \\
\hline BG & 0 & $0.0 \%$ \\
\hline CY & 0 & $0.0 \%$ \\
\hline CZ & 2,358 & $96.6 \%$ \\
\hline DE & 7 & $0.3 \%$ \\
\hline DK & 0 & $0.0 \%$ \\
\hline EE & 1 & $0.0 \%$ \\
\hline ES & 1 & $0.0 \%$ \\
\hline FI & 0 & $0.0 \%$ \\
\hline FR & 1 & $0.0 \%$ \\
\hline GB & 0 & $0.0 \%$ \\
\hline GR & 0 & $0.0 \%$ \\
\hline HR & 0 & $0.0 \%$ \\
\hline
\end{tabular}

\begin{tabular}{|l|c|c|}
\hline HU & 1 & $0.0 \%$ \\
\hline IE & 0 & $0.0 \%$ \\
\hline IT & 3 & $0.1 \%$ \\
\hline LT & 0 & $0.0 \%$ \\
\hline LU & 0 & $0.0 \%$ \\
\hline LV & 0 & $0.0 \%$ \\
\hline MT & 0 & $0.0 \%$ \\
\hline NL & 2 & $0.1 \%$ \\
\hline PL & 19 & $0.8 \%$ \\
\hline PT & 0 & $0.0 \%$ \\
\hline RO & 0 & $0.0 \%$ \\
\hline SE & 0 & $0.0 \%$ \\
\hline SI & 1 & $0.0 \%$ \\
\hline SK & 46 & $1.9 \%$ \\
\hline TOTAL & $\mathbf{2 , 4 4 0}$ & $\mathbf{1 0 0 . 0} \%$ \\
\hline
\end{tabular}

Source: own research and Amadeus database

Consequently, in order to research the distribution of MNEs tax base between the EU Member States, the group taxation schemes and consolidation schemes in individual Member States needed to be researched. Based on the research, the EU Member States can be divided into the four groups according to the applied consolidation or group taxation ruled. The categorization is presented in the following Table 4. 


\begin{tabular}{|l|l|}
\hline Full consolidation & Netherlands \\
\hline \multirow{5}{*}{ Pooling of the result on the parent company } & Denmark \\
& Germany \\
& Spain \\
& France \\
& Italy \\
& Luxembourg \\
& Austria \\
& Poland \\
& Portugal \\
\hline & Ireland \\
& Cyprus \\
& Malta \\
& Lithuania \\
& Latvia \\
& Sweden \\
& Finland \\
& United Kingdom \\
\hline Intra-group loss transfer & Belgium \\
& Bulgaria \\
& Croatia \\
& Czech republic \\
& Greece \\
& Hungary \\
& Slovak Republic \\
& Estonia \\
& Romania \\
& Slovenia \\
\hline
\end{tabular}

Source: IBFD research platform and Database Taxes in Europe

As can be clearly seen from the above stated Table 4, the only country applying fiscal unity on entities meeting certain criteria is the Netherlands. Under Dutch consolidation system the accounting profits of subsidiaries are treated in the way as they would be executed by parent company - full consolidation of incomes takes place. The group can only apply for the fiscal unity treatment if a resident company holds directly or indirectly at least $95 \%$ of the share capital of one or more other resident companies, and since 1st January 2013, the parent company must in addition also hold directly or indirectly at least $95 \%$ of the statutory voting rights in the other company.

The second group consisting of 9 EU Member States in fact enables to pool the results of the subsidiaries on the parent company. In that system the separate accounting approach is applied, but afterwards subsidiaries are allowed to offset their profits or losses at the level of the parent companies. Each of the EU Member States in that group requires companies to meet certain criteria to be granted "group treatment". Germany allows his treatment only to the companies incorporated under EU/EEA laws and controlled company must be financially integrated into the controlling parent. Denmark limits this treatment to the companies which have majority of the voting rights. Luxembourg, Poland and France 
apply the limit for group treatment on the level of $95 \%$ of voting rights. During the research there was discovered, that in Spain the pooling of the result on the parent company is mandatory for banks and their affiliates. Italy allows on top of the domestic consolidation also worldwide consolidation. The group can opt for if all the controlled entities in the tax consolidation are covered (i.e. all-in all-out principle is applied). The effect of the worldwide consolidation is that the income of the controlled companies is imputed to the controlling company (in portion according to the entitlement on the profit). Austria represents the country with one of the lowest threshold for the group treatment. Group parent companies and their subsidiaries may opt for the consolidation if the parent company exercises financial control over the subsidiary, which is presumed if the parent owns more than $50 \%$ of the capital and voting power in the subsidiary. And finally, Portugal allows forming a group for special treatment consisting of a parent company and subsidiaries in which the parent owns $90 \%$ of voting rights (directly or indirectly).

The third group of the states represents countries which are applying separate accounting approach, but profits or losses can be transferred between the members of the group. During the research it was identified again, that even in that group countries usually set the minimum threshold for voting rights. The United Kingdom differentiates two types of groups for taxation purposes: A group is made up of a parent company and its 51\% subsidiaries. In that case the only applicable relief is special arrangement for payment of the tax. The second type of the group - a consortium - consists of 20 or fewer UK resident companies that each own $5 \%$ or more, and together own $75 \%$ of a company. Consortia can qualify for the transfer of losses only. Similarly Ireland differentiates the group treatment according the level of the ownership (51\%, $75 \%$ or $90 \%$ ). A consortium exists if five or fewer companies own at least $75 \%$ of the ordinary share capital of either trading company or holding company. Losses can be transferred to any member of $75 \%$ group. Cyprus group relief is based on British model. An intra-group loss transfer is possible, provided that here is a $75 \%$ parent-subsidiary relationship, including subsidiaries under $75 \%$ control of a parent company. Malta represents the country with the lowest threshold for group treatment. Companies are considered to be members of the group if they resident in Malta and if they are $51 \%$ subsidiaries of parent company resident in Malta. In Lithuania since 1st January 2010 it has been possible to transfer losses within a group of companies under the condition that parent company holds at least $2 / 3$ of shares in a subsidiary participating in the transfer and under the condition that losses are transferred between the companies belonging continuously to the group for the minimum period of 2 years. Latvia also allows transferring of the losses among the members of the same group. The group is defined as principal enterprise and all its subsidiaries. Principal enterprise is considered as legal person or individual that is resident in Latvia or in a state with which Latvia concluded double taxation treaty. The threshold for the relation between the principal enterprise and subsidiary is $90 \%$. In Sweden, the shifting of income through group contribution is allowed. If the company qualifies for the system it is entitled to deduct the amount of the paid contribution from its taxable income and the recipient company is obliged to include such a contribution in its taxable income. This system in fact means that losses of one company may be set off against the profits of the company in the same group. Finland applies similar system of group contribution as is applied in Sweden. 
Table 5 | Current Division of the Subsidiaries Tax Base among the Individual Member States

\begin{tabular}{|c|c|c|c|c|c|c|c|c|c|c|}
\hline \multirow{2}{*}{$\begin{array}{l}\text { Section } \\
\text { of } \\
\text { NACE* }\end{array}$} & \multicolumn{2}{|c|}{$\begin{array}{l}\text { Total tax base for } \\
\text { individual sections }\end{array}$} & \multicolumn{8}{|c|}{$\begin{array}{l}\text { Division of the subsidiaries tax base among the individual Member States } \\
\text { in the EUR }\end{array}$} \\
\hline & $\begin{array}{l}\text { Abs. } \\
\text { in the EUR }\end{array}$ & $\begin{array}{l}\text { Rel. } \\
\text { in } \%\end{array}$ & $C Z$ & DE & EE & ES & HU & PL & SI & SK \\
\hline A & $1,662.98$ & 0.12 & $1,662.98$ & & & & & & & \\
\hline B & $7,836.13$ & 0.59 & $7,836.13$ & & & & & & & \\
\hline C & $131,189.53$ & 9.81 & $110,250.21$ & 11480.66 & 15.77 & & 11.95 & 711.70 & 219.55 & $8,499.69$ \\
\hline D & $245,378.31$ & 18.34 & $245,367.75$ & & & & & & & 10.55 \\
\hline $\mathbf{E}$ & $13,005.68$ & 0.97 & $12,954.57$ & & & & & 51.11 & & \\
\hline $\mathbf{F}$ & $8,565.08$ & 0.64 & $8,565.08$ & & & & & & & 0.00 \\
\hline G & $393,012.35$ & 29.38 & $341,385.50$ & $4,114.28$ & & 102.91 & & 648.61 & & $46,761.05$ \\
\hline H & $21,083.70$ & 1.58 & $21,083.70$ & & & & & 0.00 & & \\
\hline I & $1,813.40$ & 0.14 & $1,813.40$ & & & & & & & \\
\hline J & $44,575.00$ & 3.33 & $44,539.55$ & & & & & & & 35.45 \\
\hline K & $230,608.59$ & 17.24 & $205,202.73$ & $25,405.86$ & & & & & & \\
\hline $\mathbf{L}$ & $53,965.04$ & 4.03 & $53,896.93$ & 7.41 & & & & & & 60.69 \\
\hline M & $93,967.80$ & 7.02 & $93,671.09$ & & & & & 2.71 & & 294.00 \\
\hline $\mathbf{N}$ & $4,004.59$ & 0.30 & $3,995.51$ & & & & & & & 9.08 \\
\hline 0 & $73,767.32$ & 5.51 & $73,767.32$ & & & & & & & \\
\hline $\mathbf{P}$ & 556.73 & 0.04 & 556.73 & & & & & & & \\
\hline $\mathbf{Q}$ & $2,376.40$ & 0.18 & $2,376.40$ & & & & & & & \\
\hline $\mathbf{R}$ & $10,347.26$ & 0.77 & $10,347.26$ & & & & & & & \\
\hline $\mathbf{S}$ & 24.53 & $0.00 * *$ & 24.53 & & & & & & & \\
\hline $\begin{array}{l}\text { Total } \\
\text { abs. }\end{array}$ & $1,337,740.42$ & 100 & $1,239,297.38$ & $41,008.21$ & 15.77 & 102.91 & 11.95 & $1,414.14$ & 219.55 & $55,670.51$ \\
\hline $\begin{array}{l}\text { Total rel. } \\
\text { in } \%\end{array}$ & 100 & - & 92.64 & 3.07 & 0.0012 & 0.0077 & 0.0009 & 0.11 & 0.02 & 4.16 \\
\hline
\end{tabular}

Note: * A - Agriculture, forestry and fishing, B - Mining and quarrying, C - Manufacturing, D - Electricity, gas, steam and air conditioning supply, E - Water supply; sewerage; waste management and remediation activities, F - Construction, G - Wholesale and retail trade; repair of motor vehicles and motorcycles, $\mathrm{H}$ - Transporting and storage, I - Accommodation and food service activities, J - Information and communication, K - Financial and insurance activities, L - Real estate activities, M - Professional, scientific and technical activities, $\mathrm{N}$ - Administrative and support service activities, $\mathrm{O}$ - Public administration and defence; compulsory social security, P - Education, Q - Human health and social work activities, R - Arts, entertainment and recreation, $\mathrm{S}$ - Other services activities.

** 0.0018

Source: own research and Amadeus database 
Fourth group of states covers 10 EU Member States, where is not possible to compensate losses due to the reason that in those countries no group taxation schemes are available. It can be considered, that for this group of countries CCCTB will represent the most attractive tool how to reach the possibility of group taxation and offsetting of losses within the group.

Further, based on the above mentioned categorization the tax base of each of the group according to the country and consolidation status was calculated. As the individual tax base of the each subsidiary the indicator, profit or loss before taxation were considered. As was already shown above, in the case that the P/L before tax was not reported, the companies were excluded from the analysis.

Finally, the sum of tax basis for individual countries is calculated, both absolutely and relatively to the total tax base of all the subsidiaries of Czech parent companies, which are resident in the EU28. The following Table 5 summarizes the Czech parent companies according to the NACE sections and presents the final results - the map of the division of the subsidiaries taxes base between the individual Member States in current situation (i.e. in situation when CCCTB is not applied).

As can be seen, the subsidiaries' tax bases of Czech parent companies are mainly distributed among the Czech Republic (92.64\%) and the Slovak Republic (4.16\%). Both belong to the group of countries without any possibility of group treatment for tax purposes. The largest share of the total tax base is generated in the section of NACE - G (29.38\%), D (18.34\%) and K (17.24\%).

Further, sharing of the group tax base according to the allocation formula in individual EU Member States was researched. Instead of the national consolidation and group tax regimes as was performed above, the formulary apportionment was applied. Within the CCCTB system allocation formula has three equally weighted factors - sales, labour and assets. The data were gained from the accounting reports of the companies from the Amadeus database. However, the required information on the above three factors was often missing.

In order to preserve the same sample as in case of the tax base distribution analysis based on the national rules and according to Cline et al. (2010), missing data were imputed based on the observed data for companies in the same industry for Eastern and Western Europe (i.e. the EU-13 and EU-15). Missing operating revenue, number of employees, and costs of employees were imputed using ratios of the factor to assets for companies in which both variables are observed. Companies reporting fixed assets as not available were excluded from the imputation. This represented $38 \%$ of all companies.

Operating revenue was reported for $76 \%$ of CZ group companies. As already applied by Cline et al. (2010) missing operating revenue amounts were imputed using reported tangible fixed asset data and the ratio of observed operating revenue to the tangible fixed assets for other companies. Missing data was imputed by industry for Eastern and Western Europe.

Number of employees was missing in $60 \%$ of CZ group companies. Similarly as Cline et al. (2010) missing employee data were imputed based on the reported tangible fixed assets of the company and the ratio of reported employees to tangible fixed assets by industry for Eastern and Western Europe.

Payroll was missing in 65\% of CZ group companies. And finally, missing cost of employment data were imputed based on the reported or imputed employee headcount and the ratio of cost of employees and employee headcount for companies reporting both items.

Following table summarizes the results of sharing the tax base of the subsidiaries according to the allocation formula within the CCCTB system. As can be seen, the subsidiaries' 
tax bases of Czech parent companies are mainly distributed among the Czech Republic (93.86\%) and the Slovak Republic (4.34\%) as well. The largest share of total CCCTB is generated in the section of NACE - G (30.04\%), D (19.23\%) and K (15.83\%).

Table 6 | Division of the Subsidiaries Tax Base among the Individual Member States according to the Allocation Formula

\begin{tabular}{|c|c|c|c|c|c|c|c|c|c|c|}
\hline \multirow{3}{*}{$\begin{array}{l}\text { Section } \\
\text { of } \\
\text { NACE* }\end{array}$} & \multicolumn{2}{|c|}{$\begin{array}{c}\text { Total CCCTB for } \\
\text { individual sections }\end{array}$} & \multirow{2}{*}{\multicolumn{8}{|c|}{$\begin{array}{l}\text { Division of the subsidiaries CCCTB among the individual Member States } \\
\text { in the EUR }\end{array}$}} \\
\hline & \multirow{2}{*}{$\begin{array}{l}\text { Abs. } \\
\text { in the EUR }\end{array}$} & \multirow{2}{*}{$\begin{array}{l}\text { Rel. } \\
\text { in } \%\end{array}$} & & & & & & & & \\
\hline & & & CZ & DE & EE & ES & HU & PL & SI & SK \\
\hline A & $1,521.89$ & 0.12 & $1,521.89$ & & & & & & & \\
\hline B & $7,816.47$ & 0.63 & $7,816.47$ & & & & & & & \\
\hline C & $111,772.73$ & 8.94 & $95,259.76$ & $11,623.50$ & 2.86 & & 1.64 & 268.21 & 219.55 & $4,397.21$ \\
\hline D & $240,269.68$ & 19.23 & $240,269.68$ & & & & & & & 0.00 \\
\hline E & $12,512.40$ & 1.00 & $12,453.75$ & & & & & 58.65 & & \\
\hline $\mathbf{F}$ & $8,318.60$ & 0.67 & $8,318.60$ & & & & & & & 0.00 \\
\hline G & $375,377.69$ & 30.04 & $318,774.68$ & $6,297.89$ & & 276.62 & & 322.64 & & $49,705.86$ \\
\hline $\mathbf{H}$ & $20,988.33$ & 1.68 & $20,988.33$ & & & & & 0.00 & & \\
\hline I & $1,265.07$ & 0.10 & $1,265.07$ & & & & & & & \\
\hline J & $44,450.66$ & 3.56 & $44,414.01$ & & & & & & & 36.65 \\
\hline K & $197,869.66$ & 15.83 & $194,506.59$ & $3,363.07$ & & & & & & \\
\hline $\mathbf{L}$ & $50,614.28$ & 4.05 & $50,544.70$ & 8.89 & & & & & & 60.69 \\
\hline$M$ & $90,911.37$ & 7.27 & $90,856.80$ & & & & & 3.48 & & 51.09 \\
\hline $\mathbf{N}$ & $3,958.15$ & 0.32 & $3,949.07$ & & & & & & & 9.08 \\
\hline 0 & $68,929.75$ & 5.51 & $68,929.75$ & & & & & & & \\
\hline $\mathbf{P}$ & 548.46 & 0.04 & 548.46 & & & & & & & \\
\hline $\mathbf{Q}$ & $2,370.58$ & 0.19 & $2,370.58$ & & & & & & & \\
\hline $\mathbf{R}$ & $10,233.22$ & 0.81 & $10,233.22$ & & & & & & & \\
\hline $\mathbf{S}$ & 20.54 & 0.01 & 20.54 & & & & & & & \\
\hline $\begin{array}{l}\text { TOTAL } \\
\text { abs. }\end{array}$ & $1,249,749.53$ & 100 & $1,173,041,95$ & $21,293.35$ & 2.86 & 276.62 & 1.64 & 652.98 & 219.55 & $54,260.58$ \\
\hline $\begin{array}{l}\text { TOTAL } \\
\text { rel.in } \%\end{array}$ & 100 & - & 93.86 & 1.70 & $0.00 * *$ & 0.02 & $0.00 * * *$ & 0.05 & 0.02 & 4.34 \\
\hline
\end{tabular}

Note: * A - Agriculture, forestry and fishing, B - Mining and quarrying, C - Manufacturing, D - Electricity, gas, steam and air conditioning supply, E - Water supply; sewerage; waste management and remediation activities, F - Construction, G - Wholesale and retail trade; repair of motor vehicles and motorcycles, $\mathrm{H}$ - Transporting and storage, I - Accommodation and food service activities, J - Information and communication, K - Financial and insurance activities, L - Real estate activities, M - Professional, scientific and technical activities, $\mathrm{N}$ - Administrative and support service activities, $\mathrm{O}$ - Public administration and defence; compulsory social security, P - Education, Q - Human health and social work activities, R - Arts, entertainment and recreation, $\mathrm{S}$ - Other services activities.

**0.0002, ***0.0001

Source: own research and Amadeus database 
Based on the above mentioned findings, it can be considered that the introduction of CCCTB system with the possibility of full cross-border consolidation regimes will change the amount of the tax bases taxed in each jurisdiction due to the possibility of tax consolidation. The predicted changes in comparison with current situation are presented in following table.

Table 7 | Changes in the Division of Tax Bases across the EU Member States

\begin{tabular}{|c|c|c|c|c|c|c|c|c|c|}
\hline $\begin{array}{l}\text { Current } \\
\text { situation }\end{array}$ & $C Z$ & DE & EE & ES & HU & PL & SI & SK & Total \\
\hline $\begin{array}{l}\text { Total abs. } \\
\text { in the EUR }\end{array}$ & $1,239,297.38$ & $41,008.21$ & 15.77 & 102.91 & 11.95 & $1,414.14$ & 219.55 & $55,670.51$ & $1,337,740.42$ \\
\hline $\begin{array}{l}\text { Total rel. } \\
\text { in } \%\end{array}$ & 92.64 & 3.06 & 0.0012 & 0.0077 & 0.0009 & 0.11 & 0.02 & 4.16 & 100 \\
\hline \multicolumn{10}{|c|}{ CCCTB application } \\
\hline $\begin{array}{l}\text { TOTAL abs. } \\
\text { in the EUR }\end{array}$ & $1,173,041.95$ & $21,293.35$ & 2.86 & 276.62 & 1.64 & 652.98 & 219.55 & $54,260.58$ & $1,249,749.53$ \\
\hline $\begin{array}{l}\text { TOTAL rel. } \\
\text { in } \%\end{array}$ & 93.86 & 1.70 & 0.0002 & 0.02 & 0.0001 & 0.05 & 0.02 & 4.34 & 100 \\
\hline
\end{tabular}

Source: own research

\section{Conclusion}

The aim of the paper was to research the differences in the division of the MNEs group tax bases between the individual Member States in current situation - i.e. when applying separate entity approach and situation when CCCTB will be introduced - i.e. applying the allocation formula for sharing the tax base. The comparative analysis of the national consolidation and group taxation rules revealed that at present, Member States can be categorized into the four groups. Full consolidation is available only in the Netherlands. All the other Member States are applying separate accounting approach. Pooling of the profit or loss on the parent company is allowed in nine Member States and intra-group loss transfer can be done in eight Member States. The research even revealed that there are Member States in which is not available any group taxation scheme.

The research performed in the paper revealed that it can be considered that the introduction of CCCTB system with the possibility of full cross-border consolidation regimes will change the amount of the tax bases taxed in each jurisdiction due to the possibility of tax consolidation. Current division of tax bases of subsidiaries of Czech parent companies in the EU28. As can be seen from the Table 7, most of the tax bases (92.64\%) are situated in the Czech Republic, which belongs to the country where any group taxation scheme is available. The second largest share of tax bases of groups with Czech parent companies is situated in the Slovak Republic (4.16\%) as well the country without any possibility of group treatment for tax purposes. On the contrary, the third largest share of tax base of groups with Czech parent companies is situated in Germany (3.06\%), which allows pooling. Further, another country which allows pooling is Poland (0.11\%). Very small part of the tax base is situated in Spain, Estonia, Hungary and Slovenia. 
Whereas in case that the group tax bases would be shared according to the allocation formula with three equally weighted factors (sales, payroll and assets), the tax bases situated in the Czech Republic would increase to $93.86 \%$ (by 1.22\%). In addition, the tax bases situated in Slovenia, Spain and the Slovak Republic would record a very slight increase. On the contrary, Germany would face a decrease in the tax bases to $1.70 \%$ (by $1.36 \%$ ) as well Poland, Estonia and Hungary This situation is caused by the fact that under CCCTB the tax base is shared according to the factors as sales, payroll or assets. This means that even though the subsidiary in the group has negative tax base or zero tax base, it can bring the share on the tax base into the Member State according to the allocation formula.

The results presented above indicate that there might be relation between decrease/ increase in the share in the group tax base and the size of the state. Therefore the aim of further research will be to research this relationship and to predict the budgetary impacts on the Czech Republic.

\section{References}

Agúndez-García, A. (2006), "The Delineation and Apportionment of an EU Consolidated Tax Base for Multi-jurisdictional Corporate Income Taxation: A Review of Issues and Options." European Commission, Working Paper No. 9/2006.

Bettendorf, L., Van der Horst, A., de Mooij, R., Vrijburg, H. (2010), “Corporate Tax Consolidation and Enhanced Cooperation in the European Union?" Oxford University, Centre for Business Taxation, Working Paper No. 1.

Bakker, A. (2009), Transfer Pricing and Business Restructurings. Amsterdam: IBFD.

Cline, R. Neubig, T., Phillips, A., Sanger, C., Walsh, A. (2010), Study on the Economic and Budgetary Impact of the Introduction of a Common Consolidated Corporate Tax Base in the European Union, Ernst \& Young LLP.

Djanani, CH., Brahler, G. (2006), Internationales Steuerrecht. Wiesbaden: Gabler Verlag.

Devereux, M. P. (2004), “Debating Proposed Reform of the Taxation of Corporate Income in the European Union." International Tax and Public Finance, Vol. 11, No. 1, pp. 71-89.

Devereux. M. P., Loretz, S. (2007), "The Effects of EU Formula Apportionment on Corporate Tax Revenues." Oxford University, Centre for Business Taxation, Working Paper No. 8

Devereux. M. P., Loretz, S. (2008), "Increased Efficiency through Consolidation and Formula Apportionment in the European Union?" Oxford University, Centre for Business Taxation, Working Paper No. 12.

Fuest, C., Hemmelgarn, T., Ramb, F. (2006), “How Would Formula Apportionment in the EU Affect the Distribution and the Size of the Corporate Tax Base?" An Analysis Based on German Multinationals, Deutsche Bank, Discussion Paper No. 1: Economic Studies.

Goolsbee, A., Maydew, E. L. (2000), “Coveting Thy Neighbour's Manufacturing: the Dilemma of State Income Apportionment." Journal of Public Economics, Vol. 75, No. 1, pp. 125-143.

Gordon, R., Wilson, J. D. (1986), "An Examination of Multijurisdictional Corporate Income Taxation under Formula Apportionment." Econometrica, Vol. 54, No. 6, pp. 1357-1373.

Hellerstein, W., McLure, CH. E. (2004), "The European Commission Report on Company Income Taxation: What the EU Can Learn from the Experience of the US States." International Tax and Public Finance, Vol. 11, No. 2, pp. 199-220.

Jacobs, O. H. (2002), Internationale Unternehmensbesteuerung. Deutsche Investitionen im Ausland, Auslandische Investitionen im Inland. Munchen: Verlag C. H. Beck. 
Kumpf, W. (1976), Steuerliche Verrechnungspreise in internationalen Konzernen-Moglichkeiten zur Prazisierung des "dealing at arm's length" Prinzips. Frankfurt am Main: Alfred Metzner Verlag $\mathrm{GmbH}$.

Lodin, S. O., Gammie, M. (2001), Home State Taxation. Amsterdam: IBFD.

McDaniel, P. R. (1994), "Formulary Taxation in the North American Free Trade Zone." Tax Law Review, Vol. 49, No. 4, pp. 691-744.

McLure, C. E. (1980), The Economics of Taxation, Brookings Institution, Washington D.C., pp. 327-346.

Miller, B. F. (1984), “Worldwide Unitary Combination: The California Practice.” In Charles, E. and McLure, Jr. (Ed.), The State Corporation Income Tax - Issues in Worldwide Unitary Combination. Stanford: Hoover Institution Press.

Musgrave, P. (1972), "International Tax Base Division and the Multinational Corporation." Public Finance, Vol. 27, No. 4, pp. 394-413.

Musgrave, P. B. (1984), “Principles for Dividing the State Corporate Tax Base." In Charles, E. and McLure, Jr. (Ed.), The State Corporation Income Tax - Issues in Worldwide Unitary Combination. Stanford: Hoover Institution Press.

Mintz, J. M. (2004), “Corporate Tax Harmonization in Europe: It is all about Compliance." International Tax and Public Finance, Vol. 11, No. 2, pp. 221-234.

Nerudová, D. (2011), Harmonization of the Tax Systems of EU Member States. Prague: WoltersKluwer.

OECD (2001), Transfer Pricing Guidelines for Multinational Enterprises and Tax Administrations. Paris: OECD.

Oestreicher, A. (2000), Konzern-Gewinnabgrenzung-Gewinnabgrenzung, Gewinnermittlung, Gewinnaufteilung. Munchen: Verlag C. H. Beck.

Picciotto, S. (1992), International Business Taxation - A Study in the Internationalization of Business Regulation. London: Weidenfeld and Nicolson.

Solilová, V., Nerudová, D. (2012), "The Effects of Changes in Transfer Pricing Policy of the Business Models in 21st Century." Proceeding of the 17th International Conference New Role of Public Finance. Prague: Wolters Kluwer ČR, a.s., pp. 247-257.

Solilová, V., Nerudová, D. (2013) , "Transfer Pricing: General Model for Tax Planning." Journal of Economics. Vol. 61, No. 6, pp. 597-617.

Sorensen, P. B. (2004), “Company Tax Reform in the European Union." International Tax and Public Finance, Vol. 11, No. 1, pp. 91-115.

Szarowská, I. (2010), "The Effect of Tax Burden on Economic Growth in the European Union." Proceedings of the 28th International Conference on Mathematical Methods in Economics 2010. České Budějovice: University of South Bohemia, Faculty of Economics.

Vann, R. J. (1991), "A Model Tax Treaty for the Asian-Pacific Region?" Bulletin for International Fiscal Documentation, Vol. 45, No. 3, pp. 99-111.

Weiner, J. M., Mintz, J. M. (2002), "An Exploration of Formula Apportionment in the European Union." European Union, Vol. 42, No. 8, pp. 346-351.

Weiner, J. M. (1999), Using the Experience in the U.S. States to Evaluate Issues in Implementing Formula Apportionment at the International Level. U.S. Department of the Treasury OTA Paper 83.

Weiner, J. M. (2005), "Formulary Apportionment and Group Taxation in the EU: Insights from the United States and Canada." Taxation Papers, Working Paper No. 8, DG Taxation and Customs Union, European Commission. 